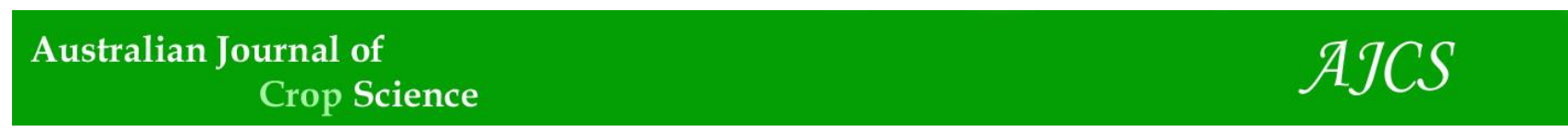

AJCS 10(3): 322-330 (2016)

ISSN:1835-2707

DOI: 10.21475/ajcs.2016.10.03.p6995

\title{
Interference of seeding and regrowth of signalgrass weed (Urochloa decumbens) during the initial development of Eucalyptus urograndis $(E$. grandis $\times E$. urophylla)
}

\author{
Allan Lopes Bacha ${ }^{1}$, Fernanda Campos Mastrotti Pereira ${ }^{1}$, Rodrigo Neto Pires ${ }^{2 *}$, Mariluce Pascoina \\ Nepomuceno ${ }^{1}$, Pedro Luís da Costa Aguiar Alves ${ }^{1}$
}

\author{
${ }^{1}$ Faculdade de Ciências Agrárias e Veterinárias, UNESP [Sao Paulo State University], Jaboticabal, Sao Paulo \\ State, Brasil \\ ${ }^{2}$ School of Plant Biology, Faculty of Science, The University of Western Australia, 35 Stirling Highway, Crawley, \\ 6009, Perth - Western Australia, Australia
}

\section{*Corresponding author: rodrigo.pires@ research.uwa.edu.au}

\begin{abstract}
Young eucalyptus seedlings in general are sensitive to stress factors during early development and establishment. Weed competition is one of the major biotic effects contributing to reductions on the initial growth of eucalyptus plants. This study aimed to evaluate the effects of different densities and distances of Urochloa decumbens seeded and regrowth during the early growth of Eucalyptus urograndis. Two experiments were conducted in an open and semi-controlled area, in a completely randomized design, in factorial arrangement $4 \times 2+1$, being respectively, four densities of weed plants $\left(2.6,5.2,7.8\right.$ and 10.4 plants $\left.\mathrm{m}^{-2}\right)$, two distances between Eucalyptus and weeds (5 and $15 \mathrm{~cm}$ ), and a weed-free control. The height and diameter of eucalyptus were evaluated 15 days intervals, and at the end of 90 days after eucalyptus planting (DAP) the leaf area and dry mass were measured. For a density of $U$. decumbens plants that were seeded at a density of 2.6 plants $\mathrm{m}^{-2}, 90$ days after Eucalyptus planting (DAP), there was a decrease in the height $(20 \%)$, stem diameter (10\%), leaf area (55\%) and dry mass $(48 \%)$. For the regrowth of $U$. decumbens at a density of 2.6 plants $\mathrm{m}^{-2}$ at $90 \mathrm{DAP}$, the height $(47 \%)$, stem diameter $(55 \%)$, leaf area $(89 \%)$ and dry mass $(87 \%)$ decreased. The results demonstrate that $U$. decumbens adversely affected the growth of eucalyptus, without statistical differences between distances, and weeds in regrowth affecting Eucalyptus growth more than seeded weeds.
\end{abstract}

Keywords: Biotic stress; Brachiaria decumbens; Competition; forestry; Weed management. Abbreviations: BRADC Urochloa decumbens; DAP Days after planting; DM Dry mass; LA Leaf area.

Introduction

According to the Brazilian Association of Planted Forest Producers, across the country, the area that is planted with Eucalyptus and Pinus increased by $2.2 \%$ compared to 2011 , reaching 6.66 million hectares in 2012. Furthermore, the weighted average productivity, which in 2005 was $36.7 \mathrm{~m}^{3}$ ha $^{-1}$ year ${ }^{-1}$, reached $40.7 \mathrm{~m}^{3}$ ha $^{-1}$ year-1 in 2012 (Abraf, 2013). This increase is directly related to the success of genetic improvement and adoption of good crop management (Stape et al., 2004) including weed management (Pereira, 2012).

Factors that affect negatively the growth of eucalyptus can be categorized into biotic and abiotic factors (Pitelli and Marchi, 1991). Regarding biotic factors, the presence of weeds has been a problematic aspect in the forestry sector around the world (Sands and Nambiar et al., 1984; Ellis et al., 1985; Caldwell et al., 1995; Adams et al., 2003; Dinardo et al., 2003; Florentine and Fox, 2003; Schaller et al., 2003; Coll et al., 2004; Garau et al., 2008; Cruz et al., 2010) as competing with crops for water, light, nutrients and releasing allelochemicals that interfere in cultural practices (Pitelli and Marchi, 1991; Toledo et al., 2001; Watt et al., 2003). Thus, it is important to note that eucalyptus seedlings are sensitive to competition imposed by these weeds especially during the establishment and early development (up to about a year old) (Pitelli and Marchi, 1991; Nambiar and Sands, 1993;
Schumann et al., 1994; Florentine and Fox, 2003; Garau et al., 2009) and may reach 52\% loss in height and $40 \%$ for diameter compared to plants grown in the absence of weed (Adams et al., 2003). Garau et al. (2009) found that there was a slight recovery of eucalyptus globulus in the third year of coexistence with weeds, but still there were significant losses in the measured variables, reaching reductions of $28 \%$ for the stem diameter, $13 \%$ for height and $53 \%$ for volume than the weed-free treatment.

The weed known as signalgrass (Urochloa decumbens (Stapf) RD Webster - syn. Brachiaria decumbens) is a major weed in eucalyptus plantations in Brazil. The forestry sector has expanded into areas that were previously occupied by pasture (Toledo et al., 1999). U. decumbens has some intrinsic characteristics, such as being difficult to control (i.e. high growth rate, presence of many seeds which can remain dormant for a long period and the possibility of regrowth even after herbicide application) and high aggressive competitive behaviour. Therefore, this weed became one of the most problematic for eucalyptus plantations and can result in negative effects on most of the physiological variables in eucalyptus plants, such as transpiration rate, stomatal conductance, photosynthetic rate and water use efficiency (Santos et al., 2015). Toledo et al. (2001) found 
that from a density of 4 plants $\mathrm{m}^{-2}$, signalgrass had negative interference on eucalyptus but the information of how this weed interferes in the crop growth depending on the distance and regrowth are scarce.

The herbicides are the most cost-effective option of weed control in eucalyptus plantations (George and Brennan, 2002). Glyphosate is the most widely herbicide used commonly sprayed just before planting to control any remaining regrowth between the planting lines and to control "clumps" of grass weeds. In the planting line the control is hampered by the fact there are few efficient and selective herbicides to control grasses. Therefore, there is a large possibility that weeds even at low densities may interfere in the growth of eucalyptus plants. Thus, to better understand the competition relation between eucalyptus plants and $U$. decumbens, the present study aimed to evaluate the effect of this weed - as seeds and regrowth plants - depending on the densities and distances from hybrid Eucalyptus urograndis seedlings $(E$. grandis $\times$ E. urophylla $)$.

\section{Results}

\section{Signalgrass seeding effects}

With the exception of the height of E. urograndis distanced 5 $\mathrm{cm}$ of the $U$. decumbens (BRADC) and the stem diameter at distances 5 and $15 \mathrm{~cm}$, all of other characteristics evaluated at 90 days after planting (DAP) showed significant difference. In addition, the treatment with 2.6 plants $\mathrm{m}^{-2}$ differed significantly from the treatments that had 5.2, 7.8 and 10.4 plants $\mathrm{m}^{-2}$. The densities from 5.2 plants $\mathrm{m}^{-2}$ did not differed significantly from each other. At $30 \mathrm{DAP}$, there were no difference between treatments in any of evaluated characteristics (Tables 1 and 2).

\section{Plants height and stem diameter}

E. urograndis plants heights at 90 DAP for both weed distances $(5$ and $15 \mathrm{~cm}$ ), showed that the free weed control grew approximately $20 \%$ more than the treatments with weeds. Compared to treatment with 5.2 or more plants $\mathrm{m}^{-2}$, the growth of the control was on average $36 \%$ higher. At densities of 5.2, 7.8 and 10.4 plants $\mathrm{m}^{-2}$, there was significant difference on the stem diameter at 60 DAP compared to the control and the treatment with 2.6 plants $\mathrm{m}^{-2}$, in both distances. In addition, already at 90 DAP, at 2.6 plants $\mathrm{m}^{-2}$, the stem diameter was less sensitive to interference imposed by weeds than were the other evaluated variables. This resulted possibly because diameter grew by $11.94 \%$ less than did the control at a distance of $5 \mathrm{~cm}$ and $7.44 \%$ less than the control for the higher distance. In contrast, eucalyptus plants from the other treatments increased on average in the same period, $39.7 \%$ less than control, both at $5 \mathrm{~cm}$ to $15 \mathrm{~cm}$, with no significant difference between them (Tables 1 and 2).

\section{Dry mass and leaf area}

For the dry mass (DM), there were no significant difference regarding the sowing distances. However, there was reduction of $48 \%$ in the mean for DM for the density of 2.6 signalgrass $\mathrm{m}^{-2}$ compared to the control. Regarding the other densities, there were no differences between them as they showed an average reduction of $82 \%$ compared to the weedfree control (Table 5). There were no significant difference in the leaf area between treatments with 5.2, 7.8 and 10.4 plants $\mathrm{m}^{-2}$ of signalgrass. In addition, there was no significant differences between the distances. However, there was a mean reduction of approximately $88 \%$ when compared to the control. In the treatment with 2.6 plants $\mathrm{m}^{-2}$, the leaf area was approximately 55\% lower than the control (average of the two distances) (Table 5).

\section{Signalgrass regrowth effects}

In the regrowth of the $U$. decumbens plants, all evaluated characteristics of the E. urograndis plants (height, diameter, and dry mass and leaf area) - independently of distance were significantly different between the control and the densities, which did not differ significantly from each other. With density of 2.6 plants $\mathrm{m}^{-2}$, the characteristics evaluated in eucalyptus plants already decreased but this reduction did not progress with the increase of signalgrass densities (Tables 3 , 4 and 5). The greatest interference of signalgrass in eucalyptus plants at low densities (i.e. 2.6 plants $\mathrm{m}^{-2}$ ) that was found in the present experiment was most likely because the weed already had a fully established root system at the time that the eucalyptus were planted, competing for natural resources more effectively than the newly established plants.

\section{Height and stem diameter}

Regarding the height of E. urograndis plants at $60 \mathrm{DAP}$, it was possible to observe the negative interference of weeds ( $p$ $<0.05$ ). At $90 \mathrm{DAP}$, the treatments with $U$. decumbens showed on average $47 \%$ less growth for $5 \mathrm{~cm}$ distance and $48 \%$ for $15 \mathrm{~cm}$ when compared to the treatment without signalgrass but with no significant difference between the densities. The eucalytus stem diameter was more sensitive to competition as imposed by signalgrass than was the height, as the diameter at 45 DAP was significantly different between the control and the other treatments $(p<0.01)$. At 90 DAP, eucalyptus showed reductions of $54 \%$ when intercropped with weed plants at $5 \mathrm{~cm}$ and $56 \%$ at $15 \mathrm{~cm}$ (Tables 3 and 4).

\section{Dry mass and leaf area}

Regarding the dry mass and leaf area, the response pattern between them was similar. The control treatment differed significantly from the other densities which did not differed between them. However, these characteristics were even more sensitive compared to the height and diameter. For the distances, there were no significant difference between 5 and $15 \mathrm{~cm}$ distances. Among all of the characteristics evaluated in this experiment, the leaf area was most sensitive to the presence of the weed, as at $5 \mathrm{~cm}$, the leaf area was approximately $88 \%$ lower than that of the control, and at 15 $\mathrm{cm}$, the lowest values were $90 \%$ (Table 5).

\section{Principal component analysis (PCA)}

Based on the characteristics evaluated, the principal component analysis (PCA) showed the grouping of $E$. urograndis plants into four groups, in which the first group is formed by plants that have been grown free of weeds (weed free control), the second one consists of the treatment of weeds sown in density of 2.6 plants $\mathrm{m}^{-2}$, the third group is characterized by treatments with weed seeded in densities of 5.2, 7.8 and 10.4 plants $\mathrm{m}^{-2}$ and the group four, that fitted the treatments with all the weeds in regrowth (regardless density) (Figure 2). The PCA indicated the formation of two major components corresponding to $98.94 \%$ of the original information, they 
Table 1. Effect of different densities of Urochloa decumbens seeded $5 \mathrm{~cm}$ from Eucalyptus urograndis.

\begin{tabular}{|c|c|c|c|c|c|c|c|c|c|c|c|c|c|c|}
\hline \multirow{2}{*}{ Treatments } & \multicolumn{7}{|c|}{ Height $(\mathrm{cm})$} & \multicolumn{7}{|c|}{ Stem diameter (mm) } \\
\hline & 0 DAP & 15 DAP & 30 DAP & 45 DAP & 60 DAP & 75 DAP & $90 \mathrm{DAP}$ & 0 DAP & 15 DAP & 30 DAP & 45 DAP & 60 DAP & 75 DAP & 90 DAP \\
\hline \multicolumn{15}{|l|}{$5 \mathrm{~cm}$} \\
\hline Weed free & $29.33 \mathrm{a}$ & $29.66 \mathrm{a}$ & $35.83 \mathrm{a}$ & $47.33 \mathrm{a}$ & $69.00 \mathrm{a}$ & $87.00 \mathrm{a}$ & $99.66 \mathrm{a}$ & $1.11 \mathrm{a}$ & $3.22 \mathrm{a}$ & $4.64 \mathrm{a}$ & $9.38 \mathrm{a}$ & $12.10 \mathrm{a}$ & $13.65 \mathrm{a}$ & $14.90 \mathrm{a}$ \\
\hline 2.6 plants $\mathrm{m}^{-2}$ & $27.33 \mathrm{a}$ & $28.83 \mathrm{a}$ & $37.16 \mathrm{a}$ & $50.33 \mathrm{a}$ & $66.33 \mathrm{a}$ & $73.16 \mathrm{ab}$ & $73.83 \mathrm{ab}$ & $1.09 \mathrm{a}$ & $3.23 \mathrm{a}$ & $4.87 \mathrm{a}$ & $9.04 \mathrm{a}$ & $11.39 \mathrm{ab}$ & $12.38 \mathrm{a}$ & $13.12 \mathrm{a}$ \\
\hline 5.2 plants $\mathrm{m}^{-2}$ & $27.16 \mathrm{a}$ & $27.83 \mathrm{a}$ & $35.16 \mathrm{a}$ & $40.33 \mathrm{a}$ & $53.33 \mathrm{a}$ & $59.00 \mathrm{~b}$ & $61.33 \mathrm{~b}$ & $1.42 \mathrm{a}$ & $2.66 \mathrm{a}$ & $4.72 \mathrm{a}$ & $7.00 \mathrm{a}$ & $7.75 \mathrm{c}$ & $8.10 \mathrm{~b}$ & $9.04 \mathrm{~b}$ \\
\hline 7.8 plants $\mathrm{m}^{-2}$ & $27.00 \mathrm{a}$ & $27.5 \mathrm{a}$ & $36.50 \mathrm{a}$ & $47.66 \mathrm{a}$ & $62.00 \mathrm{a}$ & $68.50 \mathrm{~b}$ & $74.66 \mathrm{~b}$ & $1.13 \mathrm{a}$ & $3.26 \mathrm{a}$ & $4.89 \mathrm{a}$ & $7.44 \mathrm{a}$ & $9.17 \mathrm{abc}$ & $10.47 \mathrm{ab}$ & $9.60 \mathrm{~b}$ \\
\hline 10.4 plants $\mathrm{m}^{-2}$ & $28.66 \mathrm{a}$ & $29.66 \mathrm{a}$ & $38.16 \mathrm{a}$ & $51.00 \mathrm{a}$ & $56.50 \mathrm{a}$ & $62.83 \mathrm{~b}$ & $68.66 \mathrm{~b}$ & $1.06 \mathrm{a}$ & $3.00 \mathrm{a}$ & $4.63 \mathrm{a}$ & $7.24 \mathrm{a}$ & $8.10 \mathrm{bc}$ & $9.86 \mathrm{ab}$ & $9.91 \mathrm{~b}$ \\
\hline F (Trat) & $0.71 \mathrm{NS}$ & $0.96 \mathrm{NS}$ & $0.98 \mathrm{NS}$ & $1.83 \mathrm{NS}$ & $3.98 *$ & $8.32 * *$ & $10.01 * *$ & $1.26 \mathrm{NS}$ & $1.35 \mathrm{NS}$ & $0.13 \mathrm{NS}$ & $2.94 \mathrm{NS}$ & $7.29 * *$ & $5.99 * *$ & $16.37 * *$ \\
\hline $\mathrm{CV}(\%)$ & 7.62 & 6.20 & 5.55 & 11.43 & 9.62 & 9.32 & 10.34 & 19.27 & 12.39 & 12.22 & 13.86 & 12.93 & 14.10 & 9.68 \\
\hline
\end{tabular}
probability on the $f$ test

$\mathbf{\Delta}=$ U. decumbens

$0=$ Eucalyptus
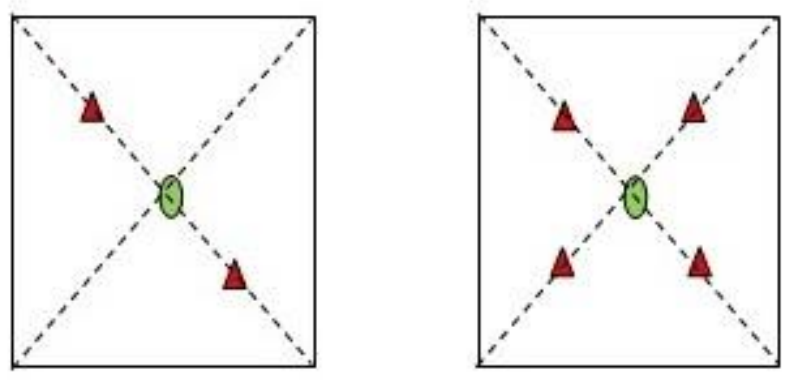

Fig 1. Example of treatments with 2 and $4 U$. decumbens. 
Table 2. Effect of different densities of Urochloa decumbens seeded $15 \mathrm{~cm}$ from Eucalyptus urograndis.

\begin{tabular}{|c|c|c|c|c|c|c|c|c|c|c|c|c|c|c|}
\hline \multirow{2}{*}{ Treatments } & \multicolumn{2}{|c|}{ Height $(\mathrm{cm})$} & \multirow{2}{*}{$30 \mathrm{DAP}$} & \multirow{2}{*}{$45 \mathrm{DAP}$} & \multirow{2}{*}{$60 \mathrm{DAP}$} & \multirow{2}{*}{75 DAP } & \multirow{2}{*}{90 DAP } & \multicolumn{3}{|c|}{ Stem diameter $(\mathrm{mm})$} & \multirow[b]{2}{*}{45 DAP } & \multirow[b]{2}{*}{60 DAP } & \multirow[b]{2}{*}{75 DAP } & \multirow[b]{2}{*}{$90 \mathrm{DAP}$} \\
\hline & $\begin{array}{l}0 \text { DAP } \\
15 \mathrm{~cm}\end{array}$ & $15 \mathrm{DAP}$ & & & & & & 0 DAP & 15 DAP & $30 \mathrm{DAP}$ & & & & \\
\hline Weed free & $29.33 \mathrm{a}$ & $29.66 \mathrm{a}$ & $35.83 \mathrm{a}$ & $47.33 \mathrm{a}$ & $69.00 \mathrm{a}$ & $87.00 \mathrm{a}$ & $99.66 \mathrm{a}$ & $1.11 \mathrm{a}$ & $3.22 \mathrm{a}$ & $4.64 \mathrm{a}$ & $9.38 \mathrm{a}$ & $12.10 \mathrm{a}$ & $13.65 \mathrm{a}$ & $14.90 \mathrm{a}$ \\
\hline${ }_{2}^{2.6}$ plants $\mathrm{m}^{-}$ & $27.83 \mathrm{a}$ & $28.83 \mathrm{a}$ & $33.16 \mathrm{a}$ & $49.00 \mathrm{a}$ & $62.00 \mathrm{ab}$ & $73.33 \mathrm{ab}$ & $77.00 \mathrm{~b}$ & $1.18 \mathrm{a}$ & $3.04 \mathrm{a}$ & $4.53 \mathrm{a}$ & $9.30 \mathrm{a}$ & $11.13 \mathrm{a}$ & $12.43 \mathrm{a}$ & $13.78 \mathrm{a}$ \\
\hline${ }_{2} .2$ plants $\mathrm{m}^{-}$ & $27.83 \mathrm{a}$ & $28.00 \mathrm{a}$ & $35.50 \mathrm{a}$ & $41.00 \mathrm{a}$ & $57.16 \mathrm{ab}$ & $56.33 \mathrm{~b}$ & $64.66 \mathrm{~b}$ & $1.19 \mathrm{a}$ & $2.97 \mathrm{a}$ & $4.63 \mathrm{a}$ & $6.80 \mathrm{~b}$ & $7.97 \mathrm{~b}$ & $8.29 \mathrm{~b}$ & $9.42 \mathrm{~b}$ \\
\hline${ }_{2}^{7.8}$ plants $\mathrm{m}^{-}$ & $27.50 \mathrm{a}$ & $27.66 \mathrm{a}$ & $31.83 \mathrm{a}$ & $41.33 \mathrm{a}$ & $48.66 \mathrm{~b}$ & $54.66 \mathrm{~b}$ & $63.66 \mathrm{~b}$ & $1.09 \mathrm{a}$ & $2.76 \mathrm{a}$ & $4.52 \mathrm{a}$ & $6.59 \mathrm{~b}$ & $7.84 \mathrm{~b}$ & $7.56 \mathrm{~b}$ & $8.14 \mathrm{~b}$ \\
\hline $\begin{array}{l}10.4 \\
\mathrm{~m}^{-2}\end{array}$ plants & $29.33 \mathrm{a}$ & $30.16 \mathrm{a}$ & $37.33 \mathrm{a}$ & $41.00 \mathrm{a}$ & $54.33 \mathrm{ab}$ & $62.33 \mathrm{~b}$ & $67.83 \mathrm{~b}$ & $1.31 \mathrm{a}$ & $2.82 \mathrm{a}$ & $4.50 \mathrm{a}$ & $6.97 \mathrm{ab}$ & $7.99 \mathrm{~b}$ & $8.18 \mathrm{~b}$ & $8.37 \mathrm{~b}$ \\
\hline $\mathrm{F}$ (Trat) & $0.38 \mathrm{NS}$ & $0.80 \mathrm{NS}$ & $1.78 \mathrm{NS}$ & $2.95 \mathrm{NS}$ & $4.19 *$ & $9.19 * *$ & $10.06^{* *}$ & $0.67 \mathrm{NS}$ & $1.37 \mathrm{NS}$ & $0.17 \mathrm{NS}$ & $6.93 * *$ & $30.11 * *$ & $15.56 * *$ & $32.96 * *$ \\
\hline $\mathrm{CV}(\%)$ & 8.82 & 7.81 & 8.23 & 8.97 & 11.21 & 11.58 & 10.97 & 15.49 & 9.20 & 5.86 & 11.84 & 6.87 & 12.27 & 8.79 \\
\hline
\end{tabular}

probability on the $\mathrm{f}$ test

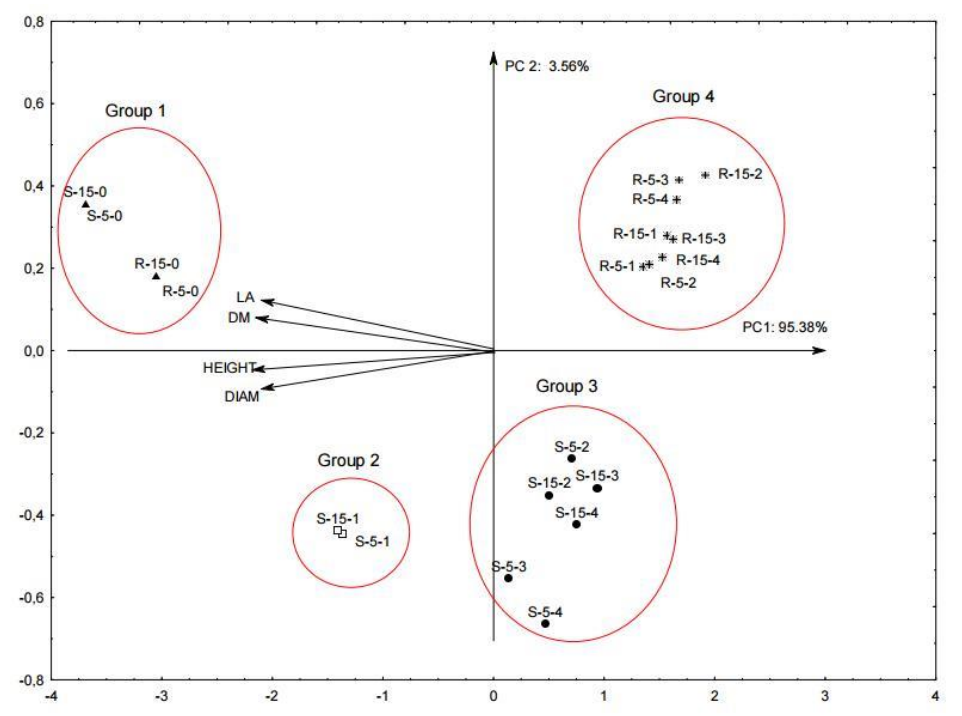

Fig 2. Principal component analysis (PCA) of $\mathrm{PC} 1$ and $\mathrm{PC} 2$ with the variables: leaf area, dry mass, height and stem diameter of eucalyptus plants.

Meanings of abbreviations: $\mathrm{S}$ or $\mathrm{R}=$ weeds seeded or in regrowth. 5 or $15=$ distance between Eucalyptus urograndis plants and weeds. $0,1,2,3$ or $4=$ density of weeds per pot (respectively weed free, 2.6, 5.2, 7.8 and 10.4 plants $\mathrm{m}^{-2}$ ). 
Table 3. Effect of different densities of Urochloa decumbens regrowth $5 \mathrm{~cm}$ from Eucalyptus urograndis.

\begin{tabular}{|c|c|c|c|c|c|c|c|c|c|c|c|c|c|c|}
\hline \multirow{2}{*}{ Treatments } & \multicolumn{7}{|c|}{ Height $(\mathrm{cm})$} & \multicolumn{7}{|c|}{ Stem diameter $(\mathrm{mm})$} \\
\hline & 0 DAP & 15 DAP & 30 DAP & 45 DAP & 60 DAP & 75 DAP & 90 DAP & 0 DAP & 15 DAP & 30 DAP & 45 DAP & 60 DAP & 75 DAP & 90 DAP \\
\hline \multicolumn{15}{|l|}{$5 \mathrm{~cm}$} \\
\hline Weed free & $35.16 \mathrm{a}$ & $38.66 \mathrm{a}$ & $45.50 \mathrm{a}$ & $49.33 \mathrm{a}$ & $60.33 \mathrm{a}$ & $81.33 \mathrm{a}$ & $91.33 \mathrm{a}$ & $3.51 \mathrm{a}$ & $3.97 \mathrm{a}$ & $5.47 \mathrm{a}$ & $6.91 \mathrm{a}$ & $9.81 \mathrm{a}$ & $13.14 \mathrm{a}$ & $13.96 \mathrm{a}$ \\
\hline 2.6 plants $\mathrm{m}^{-2}$ & $35.16 \mathrm{a}$ & $39.00 \mathrm{a}$ & $43.00 \mathrm{a}$ & $45.00 \mathrm{ab}$ & $48.33 \mathrm{~b}$ & $51.00 \mathrm{~b}$ & $52.00 \mathrm{~b}$ & $2.92 \mathrm{a}$ & $3.72 \mathrm{a}$ & $5.09 \mathrm{ab}$ & $4.63 \mathrm{~b}$ & $5.44 \mathrm{~b}$ & $6.30 \mathrm{~b}$ & $6.99 \mathrm{~b}$ \\
\hline 5.2 plants $\mathrm{m}^{-2}$ & $34.00 \mathrm{a}$ & $38.66 \mathrm{a}$ & $42.66 \mathrm{a}$ & $43.66 \mathrm{~b}$ & $44.66 \mathrm{~b}$ & $47.33 \mathrm{~b}$ & $51.33 \mathrm{~b}$ & $2.83 \mathrm{a}$ & $3.24 \mathrm{a}$ & $4.10 \mathrm{~b}$ & $4.88 \mathrm{~b}$ & $5.30 \mathrm{~b}$ & $6.03 \mathrm{~b}$ & $6.49 \mathrm{~b}$ \\
\hline 7.8 plants $\mathrm{m}^{-2}$ & $33.66 \mathrm{a}$ & $37.50 \mathrm{a}$ & $40.33 \mathrm{a}$ & $43.16 \mathrm{~b}$ & $43.66 \mathrm{~b}$ & $46.66 \mathrm{~b}$ & $47.66 \mathrm{~b}$ & $3.09 \mathrm{a}$ & $3.27 \mathrm{a}$ & $4.31 \mathrm{~b}$ & $4.85 \mathrm{~b}$ & $5.15 \mathrm{~b}$ & $5.94 \mathrm{~b}$ & $6.01 \mathrm{~b}$ \\
\hline 10.4 plants $\mathrm{m}^{-2}$ & $35.83 \mathrm{a}$ & $38.33 \mathrm{a}$ & $42.00 \mathrm{a}$ & $44.00 \mathrm{~b}$ & $45.00 \mathrm{~b}$ & $47.66 \mathrm{~b}$ & $47.66 \mathrm{~b}$ & $3.32 \mathrm{a}$ & $3.49 \mathrm{a}$ & $4.13 \mathrm{~b}$ & $4.32 \mathrm{~b}$ & $5.14 \mathrm{~b}$ & $5.70 \mathrm{~b}$ & $6.23 \mathrm{~b}$ \\
\hline F (Trat) & $0.72 \mathrm{NS}$ & $0.44 \mathrm{NS}$ & $2.70 \mathrm{NS}$ & $5.41 *$ & $31.95 * *$ & $37.83 * *$ & $61.03^{* *}$ & $2.40 \mathrm{NS}$ & $1.27 \mathrm{NS}$ & $7.71 * *$ & $23.35 * *$ & $77.53 * *$ & $115.12 * *$ & $84.40^{* *}$ \\
\hline $\mathrm{CV}(\%)$ & 5.28 & 3.83 & 4.62 & 4.12 & 4.37 & 7.67 & 7.16 & 10.10 & 13.35 & 8.38 & 7.17 & 6.50 & 6.97 & 8.04 \\
\hline
\end{tabular}

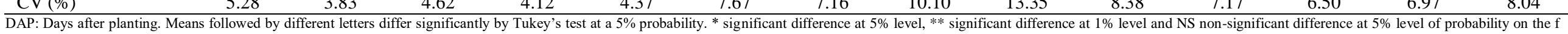

DAP. Days after planting. Means followed by different letters differ significantly by Tukey's test at a $5 \%$ probability. * significant differen
test

Table 4. Effect of different densities of Urochloa decumbens regrowth $15 \mathrm{~cm}$ from Eucalyptus urograndis.

\begin{tabular}{|c|c|c|c|c|c|c|c|c|c|c|c|c|c|c|}
\hline \multirow{2}{*}{ Treatments } & \multicolumn{7}{|c|}{ Height $(\mathrm{cm})$} & \multicolumn{7}{|c|}{ Stem diameter $(\mathrm{mm})$} \\
\hline & 0 DAP & 15 DAP & $30 \mathrm{DAP}$ & 45 DAP & 60 DAP & 75 DAP & 90 DAP & $0 \mathrm{DAP}$ & 15 DAP & 30 DAP & $45 \mathrm{DAP}$ & 60 DAP & 75 DAP & 90 DAP \\
\hline \multicolumn{15}{|l|}{$15 \mathrm{~cm}$} \\
\hline Weed free & $35.16 \mathrm{a}$ & $38.66 \mathrm{a}$ & $45.50 \mathrm{a}$ & $49.33 \mathrm{a}$ & $60.33 \mathrm{a}$ & $81.33 \mathrm{a}$ & $91.33 \mathrm{a}$ & $3.51 \mathrm{a}$ & $3.97 \mathrm{a}$ & $5.47 \mathrm{a}$ & $6.91 \mathrm{a}$ & $9.81 \mathrm{a}$ & $13.14 \mathrm{a}$ & $13.96 \mathrm{a}$ \\
\hline 2.6 plants $\mathrm{m}^{-2}$ & $38.00 \mathrm{a}$ & $38.83 \mathrm{a}$ & $42.66 \mathrm{ab}$ & $43.50 \mathrm{ab}$ & $46.33 \mathrm{~b}$ & $50.66 \mathrm{~b}$ & $51.66 \mathrm{~b}$ & $2.77 \mathrm{a}$ & $3.35 \mathrm{a}$ & $4.40 \mathrm{a}$ & $4.50 \mathrm{~b}$ & $5.21 \mathrm{ab}$ & $5.84 \mathrm{~b}$ & $6.14 \mathrm{~b}$ \\
\hline 5.2 plants $\mathrm{m}^{-2}$ & $32.50 \mathrm{a}$ & $33.83 \mathrm{a}$ & $38.00 \mathrm{~b}$ & $39.66 \mathrm{~b}$ & $41.33 \mathrm{~b}$ & $45.66 \mathrm{~b}$ & $47.00 \mathrm{~b}$ & $2.99 \mathrm{a}$ & $3.44 \mathrm{a}$ & $4.33 \mathrm{a}$ & $4.42 \mathrm{~b}$ & $4.70 \mathrm{c}$ & $5.20 \mathrm{~b}$ & $5.34 \mathrm{~b}$ \\
\hline 7.8 plants $\mathrm{m}^{-2}$ & $35.00 \mathrm{a}$ & $37.66 \mathrm{a}$ & $41.50 \mathrm{ab}$ & $42.83 \mathrm{ab}$ & $44.66 \mathrm{~b}$ & $46.00 \mathrm{~b}$ & $51.00 \mathrm{~b}$ & $3.15 \mathrm{a}$ & $3.94 \mathrm{a}$ & $4.74 \mathrm{a}$ & $5.05 \mathrm{~b}$ & $5.27 \mathrm{ab}$ & $5.99 \mathrm{~b}$ & $6.11 \mathrm{~b}$ \\
\hline 10.4 plants $\mathrm{m}^{-2}$ & $33.00 \mathrm{a}$ & $36.33 \mathrm{a}$ & $41.16 \mathrm{ab}$ & $45.00 \mathrm{ab}$ & $46.00 \mathrm{~b}$ & $47.66 \mathrm{~b}$ & $51.66 \mathrm{~b}$ & $2.74 \mathrm{a}$ & $3.23 \mathrm{a}$ & $4.55 \mathrm{a}$ & $5.04 \mathrm{~b}$ & $5.79 \mathrm{~b}$ & $6.70 \mathrm{~b}$ & $6.86 \mathrm{~b}$ \\
\hline F (Trat) & $2.17 \mathrm{NS}$ & $1.79 \mathrm{NS}$ & $4.70 *$ & $6.38 * *$ & $39.48 * *$ & $43.47 * *$ & $58.61 * *$ & $1.64 \mathrm{NS}$ & $2.38 \mathrm{NS}$ & $2.98 \mathrm{NS}$ & $25.95 * *$ & $98.41 * *$ & $79.95 * *$ & $102.51 * *$ \\
\hline $\mathrm{CV}(\%)$ & 7.35 & 7.21 & 5.18 & 5.49 & 4.22 & 7.39 & 7.13 & 13.97 & 10.78 & 9.79 & 6.61 & 5.90 & 8.58 & 7.90 \\
\hline
\end{tabular}

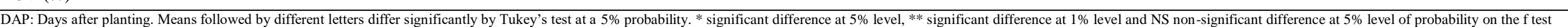

Table 5. Dry mass and leaf area from Eucalyptus urograndis in competition for 90 days with different densities of Urochloa decumbens at 5 and $15 \mathrm{~cm}$, seeded and regrown.

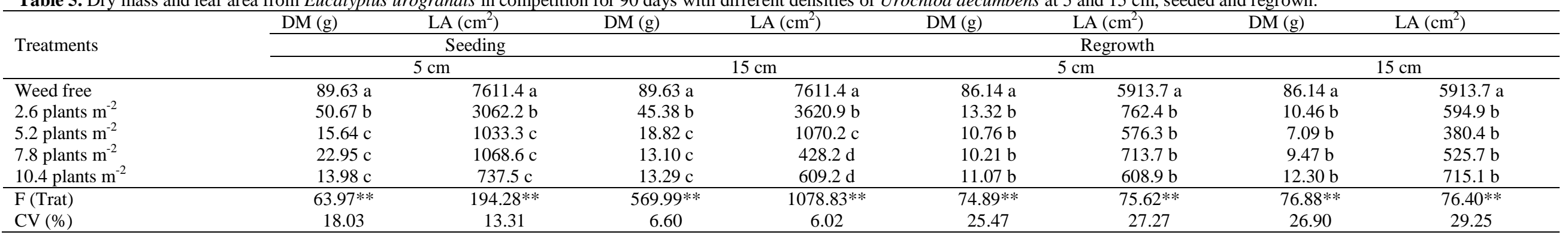

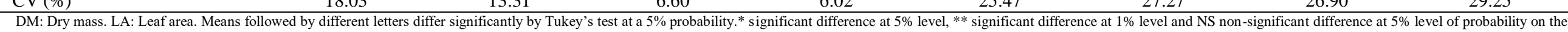

$\mathrm{f}$ test 
Table 6. Meteorological data in the Jaboticabal city region, SP, Brazil. Year 2013.

\begin{tabular}{lcccccccc}
\hline Month & Pressure $(\mathrm{hPa})$ & $\mathrm{Tmax}\left({ }^{\circ} \mathrm{C}\right)$ & $\mathrm{Tmin}\left({ }^{\circ} \mathrm{C}\right)$ & $\mathrm{Tave}\left({ }^{\circ} \mathrm{C}\right)$ & $\mathrm{RH}(\%)$ & Precipitation $(\mathrm{mm})$ & NRD & Insolation $(\mathrm{h})$ \\
\hline Jan & 942.1 & 30.2 & 19.9 & 24.0 & 79.4 & 384.0 & 18 & 189.4 \\
Feb & 942.9 & 31.0 & 20.1 & 24.3 & 78.8 & 145.2 & 15 & 191.4 \\
Mar & 943.2 & 30.1 & 19.5 & 23.8 & 80.0 & 141.6 & 13 & 193.5 \\
Apr & 944.9 & 28.5 & 17.1 & 21.8 & 77.5 & 66.3 & 9 & 197.0 \\
May & 945.5 & 28.0 & 15.3 & 20.6 & 72.9 & 93.0 & 6 & 230.3 \\
Jun & 946.5 & 27.2 & 15.4 & 20.1 & 79.3 & 31.4 & 6 & 193.3 \\
Jul & 948.2 & 26.3 & 12.4 & 18.2 & 72.5 & 33.0 & 2 & 240.1 \\
Aug & 946.9 & 29.0 & 12.3 & 19.8 & 57.0 & 0.0 & 0 & 273.8 \\
Sep & 945.4 & 30.3 & 15.9 & 22.3 & 59.5 & 66.5 & 6 & 229.7 \\
Oct & 944.2 & 30.2 & 17.4 & 23.0 & 65.6 & 90.8 & 8 & 229.4 \\
Nov & 942.1 & 30.5 & 19.3 & 24.1 & 71.4 & 161.7 & 14 & 213.5 \\
Dec & 940.2 & 31.5 & 20.1 & 24.7 & 76.2 & 239.9 & 15 & 224.5 \\
Year & 944.3 & 29.4 & 17.1 & 22.2 & 72.5 & 1453.4 & 112 & 2605.9 \\
\hline
\end{tabular}

Pressure: atmospheric pressure; Tmax: average maximum temperature; Tmin: average minimum temperature; Tave: average temperature; RH: relative humidity of air; NRD: number of rainy days

Table 7. Chemical analysis of a sample of soil taken from the experimental plot

\begin{tabular}{lcccccccccc}
$\mathrm{pH}$ in $\mathrm{CaCl}_{2}$ & $\begin{array}{c}\text { O.M. } \\
\mathrm{g} / \mathrm{dm}^{3}\end{array}$ & $\begin{array}{c}\mathrm{P} \text { resin } \\
\mathrm{mg} / \mathrm{dm}^{3}\end{array}$ & & $\mathrm{~K}$ & $\mathrm{Ca}$ & $\mathrm{Mg}$ & $\mathrm{H}^{+} \mathrm{Al}$ & $\mathrm{SB}$ & $\mathrm{T}$ & \multirow{2}{*}{$\mathrm{V} \%$} \\
\hline 6 & 22 & 310 & 7.3 & 73 & $\mathrm{mmolc} / \mathrm{dm}^{3}$ & & & \\
\hline
\end{tabular}

are: $\mathrm{PC} 1=95.38 \%$ and $\mathrm{PC} 2=3.56 \%$. This result is in accordance with criteria established by Sneath and Sokal (1973), in which the number of PC should explain at least $70 \%$ of the total variance. The variables leaf area $(\mathrm{R}=-0.97)$, dry mass $(\mathrm{R}=-0.98)$, diameter $(\mathrm{R}=-0.96)$ and height $(\mathrm{R}=$ $0.97)$ showed inverse correlation to PC1. It is possible to observe great difference between the four groups formed (Figure 2). The regrowth group (Group 4) was the one that most affect the eucalyptus growth, regardless of the weed density (also seen in the values given in Tables 3, 4 and 5). This response is due to the fact that these plants are already with their root system fully established at the time the eucalyptus trees were transplanted, which guaranteed them greater competitive advantage. For seeded weeds, it was observed that the densities above 2.6 plants $\mathrm{m}^{-2}$ (Group 3) there was no difference between them in relation to the measured variables, however they differed from all of the other groups (Figure 2). On the other hand, the weeds sown in the density of 2.6 plants $\mathrm{m}^{-2}$ (Group 2) affected the eucalyptus plants enough to differentiate them from the control (Group 1) but not to resemble the Group 3. Thus, it is evident that the weed in regrowth, irrespective of density, resulted in greater competitive effect in the growth of the eucalyptus seedlings.

\section{Discussion}

Analysing the effect of the densities of signalgrass on the early development of Eucalyptus grandis plants, Toledo et al. (2001) obtained similar results to those obtained in this present study. On this previous paper at the same period after planting, there was $18.47 \%$ reduction in the height of eucalyptus plants at a density of 4 signalgrass $\mathrm{m}^{-2}$, but there was no significant difference at greater densities of $U$. decumbens. The stem diameter data of this study are consistent with those that were obtained by Toledo et al. (2001). As at greater densities of weeds, the authors found no significant difference. Cruz et al. (2010) when analysing the interference of another grass - Panicum maximum - on the initial development of E. urograndis plants found that the number of leaves and the leaf area were significantly affected in the presence of the weed. These data corroborate those presented in this work, as well as those that were reported by
Toledo et al. (2001). Tarouco et al. (2009) obtained similar results when analysing the coexistence of $E$. urograndis plants with several weeds. The authors observed that in approximately 400 days, the difference between eucalyptus dry mass in coexistence with weeds and those that were weed free reached $400 \%$, indicating that an increasing period of coexistence increased the interference degree which was also confirmed by other authors (Nilsson and Orlander 1999; George and Brennan 2002; Coll et al., 2004; Harper et al., 2005). Working with Eucalyptus camaldulensis that was undersown with maize in Zimbabwe, Nyakanda et al. (1998) found that this combination reduced the number of weeds but not the biomass. However, this consortium reduced approximately $41 \%$ the fresh weight and $37 \%$ the volume of E. camaldulensis, with no significant difference for height. The losses were greater for eucalyptus plants that coexisted with weeds. Under these conditions, the reductions were $38 \%$ for height, $70 \%$ for fresh weight and $68 \%$ for the volume of eucalyptus, indicating that it is better to maintain the $E$. camaldulensis in consortium with maize than in the presence of weeds. Regarding the leaf area in this study, there was no significant difference between the treatments with 5.2, 7.8 and 10.4 plants $\mathrm{m}^{-2}$ at $5 \mathrm{~cm}$ from $E$. urograndis plants; in treatments with 2.6 plants $\mathrm{m}^{-2}$, the leaf area was approximately $55 \%$ lower than the control (average of the two distances). These data corroborate those that were obtained by Toledo et al. (2001), who assessed Eucalyptus grandis in the presence of $U$. decumbens and found a reduction of $63.26 \%$ in the leaf area density of 4 plants $\mathrm{m}^{-2}$. Santos et al. (2015) found that $U$. decumbens promotes negative effect on most of the physiological variables evaluated in E. urograndis plants, such as transpiration rate, stomatal conductance, photosynthetic rate and water use efficiency, presenting higher competitive capacity among the weed species studied. This may be the cause of the reductions in the variables evaluated in this study. Therefore, in an attempt to reduce the interference caused by the weed in the E. urograndis, Toledo et al. (2003) determined the need for a control of a radius of $100 \mathrm{~cm}$ along the row so that the weed interference during the initial development of eucalyptus plants could be reduced. There is a possibility that clones that were used in that study are more susceptible to signalgrass competition than other clones and were also in controlled 
environment without the absence of water or nutrient. Authors such as Bleasdale (1960), Blanco (1972) and Pitelli (1985) argue that the degree of interference that the culture suffers depends on the species including clones. Silva et al. (1997) found that Eucalyptus grandis is less sensitive to the coexistence of Brachiaria brizantha compared to Eucalyptus citriodora, supporting the statement made by the authors above.

Toledo et al. (2001) and Dinardo et al. (2003) found that from 4 plants $\mathrm{m}^{-2}$ significant interference of weeds on the crop already exists. It should be noted that for the papers mentioned above, weed seedlings (the seeds were sown, established in substrate and then transferred to the experimental plots) were used, while in the present experiment, the regrowth of the weed plant was used. However, in this study, a density of 2.6 plants $\mathrm{m}^{-2}$ of signalgrass significantly affected the growth of eucalyptus. As noted in Tables 3, 4 and 5, densities of 2.6, 5.2, 7.8 and 10.4 plants $\mathrm{m}^{-2}$ affected the development of eucalyptus plants similarly, indicating that the weed competes for nutrients more effectively when in regrowth, possibly because the plant roots are already fully developed at the time eucalyptus seedlings begins to compete, conferring an advantage to the weed.

Toledo et al. (2001) for the same period of review found that the interference of signalgrass decreased by $18.47 \%$ and $27.78 \%$, respectively the height and diameter of $E$. grandis seedlings regarding the control treatment (weed-free control). Dinardo et al. (2003) when analysing the interference of Panicum maximum during the early development of $E$. grandis found that at $190 \mathrm{DAP}$, this coexistence caused decreases of up to $22 \%$ in height and up to $46 \%$ in diameter compared to those of the control. Observing the results that were obtained in this study, it is clear that the presence of signalgrass in regrowth, even at low densities (2.6 plants $\mathrm{m}^{-}$ ${ }^{2}$ ), affected the growth of eucalyptus plants more drastically than did Panicum maximum, even though this latter species has competed with eucalyptus seedlings for a longer period of time.

The competition between the crop and weeds can causes huge losses to the producer if the coexistence is long-lasting. Watt et al. (2003) when investigating the competition between Cytisus scoparius and Pinus radiata for three years in New Zealand found a large reduction in the development of the culture. For trees that were maintained in the presence of Cytisus scoparius, there were reductions of $96 \%$ in the woody biomass, $95 \%$ in the foliage and $96 \%$ in the aboveground biomass of Pinus radiata. The height of the trees decreased from 3.2 to 1.6 meters, while the root collar diameter decreased from 99.2 to $27.9 \mathrm{~mm}$. The author also suggests that the reason for the large loss of growth in the first year is due to drought caused by competition between species. In Chile, Rubilar et al. (2008) reported that plants of Pinus radiata that were untreated with fertilizer and in the presence of weeds decreased by approximately $45 \%$ in height and $50 \%$ in the collar diameter. The authors also cited as a major factor limiting the growth of crop plants the drought caused by competition with weeds indicating that weed plants can cause a great loss in the forestry industry. In this sense, it should be noted that because of the weeds in regrowth are already with the root system established, it is likely that their ability to compete for this feature is even higher when compared to newly transplanted plants. Furthermore, information regarding the effect of the regrowth of weeds in the cultures are very scarce, raising the need for further studies, since the degree of interference is high even at low weed densities.

\section{Materials and methods}

\section{Experimental area and plant materials}

Two experiments were conducted, both in $100 \mathrm{~L}$ pots with $0.62 \times 0.62 \times 0.26$ meters of dimension, for approximately 90 days after eucalyptus planting (DAP) in a open and semicontrolled area of the Weed Laboratory of the Department of Biology Applied to Agriculture, FCAV - UNESP, Jaboticabal - SP, Brazil (latitude $21^{\circ} 15 ' 22^{\prime}$ ' S, longitude $48^{\circ} 18^{\prime} 58^{\prime \prime} \mathrm{W}$, and altitude $\left.595 \mathrm{~m}\right)$. The climate, according Köppen (1948) classification, is Cwa, subtropical, relatively dry in the winter, with summer rainfall, and an average annual temperature of $22{ }^{\circ} \mathrm{C}$ and precipitation of $1552 \mathrm{~mm}$ (monthly meteorological data of 2013 is indicated in Table 6). Furthermore, seedlings received daily irrigation to field capacity. The commercial clone GG100 (a hybrid of $E$. grandis $\times E$. urophylla) was used, the seedlings were 60 days old, without branches, average of $30 \mathrm{~cm}$ for height, 10 to 12 leafs and $1.25 \mathrm{~mm}$ of diameter. The first experiment, signalgrass se was conducted from February to April 2013, and $U$. decumbens was seeded. The second experiment, which was conducted between June and August 2013, used the regrowth of previously sown weeds. The soil that used was derived through a Dark eutrophic Oxisol that was fertilized with NPK 4-14-8 at $300 \mathrm{~kg} \mathrm{ha}^{-1}$ before the eucalyptus planting (soil analysis is indicated in Table 7).

For the second experiment, on the day of the eucalyptus planting, all of the plants of $U$. decumbens, which had about 120 days after sown, were cut at their base so that the development of seedlings could be evaluated as proposed (regrowth plants).

\section{Treatments and experimental design}

Treatments with 1, 2, 3 and 4 plants of $U$. decumbens per pot were conducted, always in the presence of eucalyptus seedlings. These amounts correspond to densities of 2.6, 5.2, 7.8 and 10.4 plants $\mathrm{m}^{-2}$. The control consisted of eucalyptus plants in the absence of weeds. Signalgrass (U. decumbens) seeds were sown along the diagonal of the box (approximately 5 seeds per planting hole), with distances of 5 and $15 \mathrm{~cm}$ between these seeds and eucalyptus (central) (Fig. 1). Approximately 15 days after sowing, manual thinning was performed, keeping only one plant of $U$. decumbens. The experimental design was a complete randomized block with 9 treatments (4 densities of signalgrass, 2 distances between the signalgrass and the seedlings and a control with only one seedling of E. urograndis) with three replications. To avoid interference from any other weed, these plants were removed by hand as necessary.

\section{Assessed variables and statistical analysis}

Evaluations were performed at 15, 30, 45, 60, 75 and 90 DAP. For E. urograndis, the following were determined: height (from ground to the apical end of the plant using a wooden ruler of $100 \mathrm{~cm}$ ) and stem diameter (digital caliper used at $1 \mathrm{~cm}$ of soil). At 90 DAP, the eucalyptus plants were cut at the base, and the leaf area was determined (LI-COR, LI 3100 ). The leaves and stems were oven-dried with forced air circulation $\left( \pm 70{ }^{\circ} \mathrm{C}\right)$ for 96 hours to obtain dry mass weight. Comparisons of results were carried out through an analysis of variance (ANOVA) for four densities, two distances and one eucalyptus specie. Separation of the means, when performed, was done using the Tukey test $(p \leq 0.05)$ 
SISVAR v. 5.5 statistical software (UFLA, Lavras, MG, Brazil) was used for statistical analyses. The average values of leaf area, dry mass, height (90 DAP) and stem diameter (90 DAP) were subjected to multivariate analysis, using the STATISTICA 7.0 statistical software (StatSoft. Inc., Tulsa, OK, USA), comprising the principal component analysis (Sneath and Sokal, 1973).

\section{Conclusion}

Urochloa decumbens plants seeded and in regrown negatively affected the initial growth of Eucalyptus urograndis being the greater effect of competition from weeds in regrowth. There was no significant difference between the tested distances $(5$ and $15 \mathrm{~cm}$ ). For the weeds sown, from a density of 2.6 plants $\mathrm{m}^{-2}$ already show a decrease in in the variables evaluated. With increasing density $\left(5.2,7.8\right.$ and 10.4 plants $\left.\mathrm{m}^{-2}\right)$ there was an increase in losses of height, diameter, leaf area and total dry mass of eucalyptus but no statistical difference between them. In any tested density of the weed in regrowth, losses in the evaluated characteristics were similar (no statistical difference between them).

\section{Acknowledgements}

The authors would like to thank all of the members of the Weed Laboratory of UNESP (LAPDA) for their support.

\section{References}

Abraf (2013) Associação brasileira dos produtores de florestas plantadas. Anuário estatístico da abraf, ano base 2012.

Adams P, Beadle C, Mendham N, Smethurst P (2003) The impact of timing and duration of grass control on the growth of a young Eucalyptus globulus Labill. plantation. New Forest. 26:147-165.

Blanco HG (1972) A importância dos estudos ecológicos nos programas de controle de plantas daninhas. Biológico. 38(10):343-350.

Bleasdale JKA (1960) Studies on plant competition. In: Harper JL (ed) The biology of weeds, Oxford, UK.

Caldwell J, Sucoff E, Dixon K (1995) Grass interference limits resource availability and reduces growth of juvenile red pine in the field. New Forest. 10:1-15.

Coll L, Balandier P, Picon-Cochard C (2004) Morphological and physiological responses of beech (Fagus sylvatica) seedlings to grass-induced belowground competition. Tree Physiol. 24:45-54.

Cruz MB, Alves PLCA, Karam D, Ferraudo AS (2010) Guinea grass and its effects on the initial growth of Eucalyptus $\times$ urograndis clones. Ciência Florestal. 20(3):391-401.

Dinardo W, Toledo REB, Alves PLCA, Pitelli RA (2003) Effect of Panicum maximum Jacq density on the initial growth of Eucalyptus grandis W. Hill ex Maiden. Scientia Forestalis. 64:59-68.

Ellis RC, Webb DP, Graley AM, Rout AF (1985) The effect of weed competition and nitrogen nutrition on the growth of seedlings of Eucalyptus delegatensis in a highland area of Tasmania. Aust Forest Res. 15:395-408.

Florentine S, Fox J (2003) Competition between Eucalyptus vitrix seedlings and grass species. Ecol Res. 18:25-39.

Garau AM, Ghersa CM, Lemcoff JH, Barañao JJ (2009) Weeds in Eucalyptus globulus subsp. maidenii (F. Muell) establishment: effects of competition on sapling growth and survivorship. New Forest. 37:251-264.

Garau AM, Lemcoff JH, Ghersa CM, Beadle CL (2008) Water stress tolerance in Eucalyptus globulus Labill. subsp. maidenii (F. Muell.) saplings induced by water restrictions imposed by weeds. Forest Ecol Manag. 255:2811-2819.

George B, Brennan P (2002) Herbicides are more costeffective than alternative weed control methods for increasing early growth of Eucalyptus dunnii and Eucalyptus saligna. New Forest. 24:147-163.

Harper G, Comeau P, Biring B (2005) A comparison of herbicide and mulch mat treatments for reducing grass, herb, and shrub competition in the BC Interior Douglas-Fir zone-Ten years results. West J Appl For. 20:167-176.

Köppen W (1948) Climatologia: con un estudio de los climas de la tierra. Fondo de Cultura Econômica. México. p 479.

Nambiar E, Sands R (1993) Competition for water and nutrients in forests. Can J Forest Res. 23:1955-1968.

Nilsson U, Orlander G (1999) Vegetation management on grass-dominated clearcuts planted with Norway spruce in southern Sweden. Can J Res. 29:1015-1026.

Nyakanda C, Chivinge OA, Ngwenya P (1998) Maize growth and weed dynamics under two-year old Eucalyptus stands. S Afr Forest J. 183:25-30.

Pereira FCM, Yamauti MS, Alves PLCA (2012) Interaction between weed management and covering fertilization in the initial growth of Eucalyptus grandis x E. urophylla. Rev Árvore. 36(5):941-949.

Pitelli RA (1985) Interferência das plantas daninhas nas culturas agrícolas. Informe agropecuário 11(129):16-27.

Pitelli RA, Marchi SR (1991) Interferência das plantas invasoras nas áreas de reflorestamento. Paper presented at the 3rd Seminário técnico sobre plantas daninhas e o uso de herbicidas em reflorestamento, Belo Horizonte, MG, Brasil, 1991.

Rubilar R, Blevins L, Toro J, Vita A, Munoz F (2008) Early response of Pinus radiata plantations to weed control and fertilization on metamorphic soils of the Coastal Range, Maule Region, Chile. Bosque. 29(1):74-84.

Sands R, Nambiar EKS (1984) Water relations of Pinus radiata in competition with weeds. Can J Forest Res. 14:233-237.

Santos MV, Ferreira EA, Tuffi Santos LD, da Fonseca DM, Aspiazu I, Silva DV, Porto JMP, Braga RR (2015) Physiological aspects of acacia and eucalyptus in competition with Brachiaria. Aust J Crop Sci. 9(3):210 214.

Schaller M, Schroth G, Beer J, Jiménez F (2003) Root interactions between young Eucalyptus deglupta trees and competitive grass species in contour strips. Forest Ecol Manag. 179:429-440.

Schumann A, Little K, Snell C (1994) Recommendations on establishment weeding intensity in Zululand: update 15 months results from three competition trials and simulation models. ICFR Bull. 3(94):1-8.

Silva W, Silva AA, Sediyama T, Freitas LHL (1997) Eucalyptus citriodora and E. grandis height and diameter growing in different water and association levels with Brachiaria brizantha. Floresta. 27:3-16.

Sneath PH, Sokal RR (1973) Numerical taxonomy: the principles and practice of numerical classification. San Francisco, USA.

Stape J, Binkley D, Ryan GR, Gomes AN (2004) Water use, water limitation, and water use efficiency in a eucalyptus plantation. Bosque. 25(2):35-41. 
Tarouco CP, Agotinetto D, Panozzo LD, Santos LSdos, Vignolo GK, Ramos LOO (2009) Weed interference periods on in the initial growth of eucalyptus. Pesqui Agropecu Bras. 44(9):1131-1137.

Toledo REB, Alves PLCA, Valle CF, Alvarenga SF (1999) Brachiaria decumbens management and effects on the crop development of Eucalyptus grandis. Scientia Forestalis. 55:129-144.

Toledo REB, Victoria Filho R, Alves PLCA, Pitelli RA, Cadini MTD (2001) Effect of Brachiaria decumbens Stapf density on the initial growth of Eucalyptus grandis W.Hill ex Maiden plants. Scientia Forestalis. 60:109-117.
Toledo REB, Victoria Filho R, Alves PLCA, Pitelli RA, Lopes MAF (2003) Weed control strip on Eucalyptus plants growth. Scientia Florestalis. 64:78-92.

Watt MS, Whitehead D, Mason EG, Richardson B, Kimberley MO (2003) The influence of weed competition for light and water on growth and dry matter partitioning of young Pinus radiata, at a dryland site. Forest Ecol Manag. 183:363-376. 